\title{
INNOVATIVE SUSTAINABLE STREETSCAPE DESIGN ALONG KEMBANG JEPUN CORRIDOR SURABAYA
}

\author{
Bambang Soemardiono*, Murni Rachmawati, Defry A Ardianta, Rahma \\ Sakinah, Muhammad Syafiq, Arie Ranuari, Arina Marta Setya Putri, Deasy \\ Tuffahati \\ *) Departement Of Architecture, Faculty of Architecture, Design and Planning \\ Institut Teknologi Sepuluh Nopember, Surabaya 60111, Indonesia \\ e-mail: bamsoem03@yahoo.com
}

\begin{abstract}
Kembang Jepun is an area of the old city of Surabaya known under the name of the Lower Town or "Beneden Stad" that developed since the 18th century which has buildings with several different periods starting in the 1870s up to the 1900s. Now Kembang Jepun area has been known as dense area filled with commercial buildings and less paying attention to the condition of the streetscape. As a historic area that continues to operate actively, Kembang Jepun corridor has great streetscape potential to be developed to produce an attractive city situation in terms of environment, social conditions and supporting urban economic development. In fact there are problems for instance lacking in greenery and safety as well as historical atmosphere. For this purpose, the study will use a focus group discussion approach, which is a method of discussion with several stakeholders to provide innovative design ideas in the development of streetscape that has meaning in sustainable urban development, because stakeholder participation is an important key factor in the sustainable design process. The expected result of this research is to develop innovative streetscape designs in the corridor by develop the potentials and still maintaining the cultural heritage buildings.
\end{abstract}

Keywords: Kembang Jepun, Streetscape, Forum Group Discussion

\section{INTRODUCTION}

Streetscape conditions in Surabaya experienced various changes. This can be seen in some streetscape points in central bussiness district area in downtown area. Kembang Jepun is an area of urban dense bussiness district that lacks good streetscape facilities. This can be seen in the Kembang Jepun Street segment which does not have access road for pedestrian and the entire road is used for motor vehicles. For that streetscape problem Kembang Jepun Area still need an innovative arrangement so that it can display the character of the old city around the north area of surabaya. Streetscape arrangement in the area of kembang jepun is intended to 
improve the circulation of good goods, vehicles and humans. Therefore, there needs to be an innovative design related in the preparation of design criteria for streetscape in Kembang Jepun area.

\section{THEORY / RESEARCH METHODS}

\section{Innovative City}

Economic and ecological sustainability can strengthen each other and benefit some parties. For example, the implementation of an integrated waste management program through a systematic implementation of stakeholders is beneficial economically and ecologically. Integrated utility and resource planning and management through systematic stakeholder collaboration can provide benefits for broader human sustainability and well coordinated and comprehensive urban development programs. Social and environmental programs demonstrated that costs are not a hindrance to ecological and economic city planning, development and management and illustration of trace success in urban development that brings together institutional and cultural space. There are 4 (four) main principles in planning an innovative city that is:

1. City based approach

2. An expanded platform for collaborative design and decision making

3. A one system approach

4. An investment framework that values sustainability and resiliency

The purpose of streetscape in the Central Business District (CBD) is to address the needs of the growing population and a desire to improve pedestrian facilities to create more walkable communities[1].

The innovative streetscape design has to address the following needs:

1. To accommodate existing driver behavior which is unique to the city due to the diverse population.

2. To design streets that create a safe environment for all users, recognizing varying levels of driver education and cultural differences.

3. To act as a tool for the transition of the CBD from a vehicle trip based society to a multi-modal society and supporting long term public transport plan.

4. To introduce fine-grained street networks that allow greater route choice for pedestrians and improve the capacity and efficiency of the streets.

The standards and guidelines in this Manual are based upon the following key design principles such as - The best transport plan is a good land use plan, Good street design starts with pedestrians, A well designed street network provides safety for all modes of transport and Street connectivity enhances capacity and allows smooth traffic flow. 


\section{Vertical garden}

Vertical Garden is a descriptive term used to refer to all vegetated wall surfaces. It is also called a system to attach plants to structures of building walls or facades of vertically greened buildings either partially or completely covered with vegetation, and have a pleasant green appearance (Yu-Peng yeh, 2010)[2].

Vertical greening states some of the benefits of using vertical green elements, including:

1. Improving Air Quality: Plants require carbon dioxide to synthesize food through direct contact of sunlight in a process called photosynthesis. The product of this process is oxygen that is beneficial to humans. The more plants are grown in the urban areas, the more oxygen will be produced automatically through the recycle of carbon dioxide.

2. The Effect of Ecology: Vertical garden can serve as an alternative ecological habitat. Certain species such as Hedera helix and rose plant (Rosa) can produce colorful fruits that can be enjoyed by animals, while vines are favored by birds and bats.

3. Increasing the Value of Urban Aesthetics: Having a vertical greening in urban space can create a positive impact in terms of availability of green space environments, where the availability of green spaces is slowly decreasing in supply. A green wall which is designed and maintained properly can improve the appearance of a building. For example, green wall can be used to disguise less attractive areas such as old untreated bridges, multilevel parking lots, old buildings with untreated facades.

4. Rain retention and solar radiation: The Green Facade can form effective protection against heavy rain, as it prevents rainwater from reaching the surface of the building facade. Rath and Kieß1 in Ottelé (2011) suggest that 50\% of the sun's energy will be absorbed and 30\% reflected by the foliage [3].

5. Effect on Environmental Temperature : The green facade can create its own microclimate, so it can affect the microclimate in the environment around the building.

\section{Type of Plants Suitable for Vertical Garden}

The use of appropriate vegetation types for vertical garden systems especially for exterior use is important. There are experimental applications of green facades in tropical climates (Thailand) by studying the plant species of Ivy labu (coccinia grandis), terompet biru (thunbergia grandiflora), and meksiko rambat (antigonon Leptopus). It was found that the Terompet Biru tree grows very fast and provides consistent density, making it suitable for covering green facades in tropical climates (Sunakorn, et al. 2011) [4].

The use of vines is a common choice for green facades, but research on living vegetation species on living walls is limited. Vegetation for living walls has a wider choice than a green facade. The types of vegetation commonly used include: 
Table 1. Types of Vegetation Commonly Used

\begin{tabular}{|c|c|c|}
\hline NO. & Name & Explanation \\
\hline 1 & $\begin{array}{l}\text { Aeschynant } \\
\text { hus radicans }\end{array}$ & $\begin{array}{l}\text { Also known as 'lipstick plant', it is a } \\
\text { suitable plant for use in vertical } \\
\text { garden applications both indoors } \\
\text { and outdoors. Plants that have good } \\
\text { growth rates in optimum lighting } \\
\text { and moist environments and are } \\
\text { able to adapt to dry environments } \\
\text { with minimal lighting. This plant } \\
\text { provides a beautiful pattern if } \\
\text { applied to the vertical garden } \\
\text { thanks to its red buds with green } \\
\text { foliage. }\end{array}$ \\
\hline
\end{tabular}

2 Nephrolepis Also known as 'Sword Fern', the exaltata best part of this plant is the ease to maintain its health and beauty. It is suitable for humid environments and is an ideal choice for outdoor applications. This plant is good in regulating the temperature so it keeps the temperature moderate and under control

3 Acacia Plants that can provide different cognata attractions to the wall with a fuller impression. Often used at the finishing touch and fits indoors or outdoors.
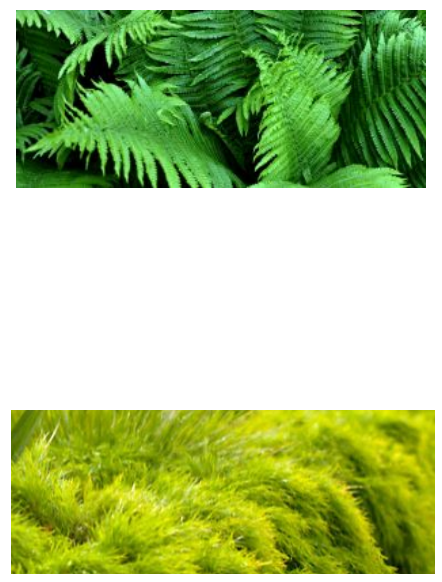

4 Dracaena

Plants that are often used in vertical garden applications, due to the unique style of the leaves and suitable in all shapes and colors of the wall as a media of application.

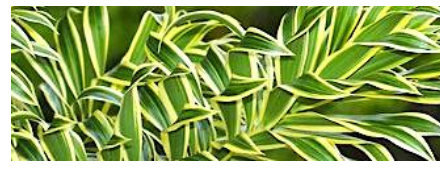

5 Stephanotis This plant is widely known as a floribunda wedding plant thanks to a white flower bud shape and can emit an attractive scent of fragrances so it fits in vertical garden applications. This plant requires exposure to high sunlight so it can grow healthily.

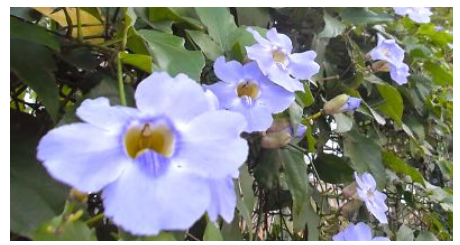


Table 1. Types of Vegetation Commonly Used (continued)

\begin{tabular}{|c|c|c|c|}
\hline NO. & Name & Explanation & Picture \\
\hline 6 & $\begin{array}{l}\text { Epipremnu } \\
\text { m aureum }\end{array}$ & $\begin{array}{l}\text { This plants known as "Australian } \\
\text { native monstera" because it requires } \\
\text { minimal maintenance. Often used } \\
\text { in vertical garden applications and } \\
\text { easily spotted from the color of the } \\
\text { leaves which are bright yellow to } \\
\text { pale yellow, it is a plant that is } \\
\text { reliable enough to require minimal } \\
\text { care and moderate exposure to } \\
\text { sunlight. }\end{array}$ & \\
\hline 7 & $\begin{array}{l}\text { Codiaeum } \\
\text { variegatum } \\
\text { pictum }\end{array}$ & $\begin{array}{l}\text { This common plant grown in } \\
\text { Indonesia is also known as 'Croton'. } \\
\text { It would grow very well if exposed } \\
\text { to direct sunlight to get good } \\
\text { staining and prettier color. In a } \\
\text { vertical garden application, this } \\
\text { plant is often used to give color } \\
\text { accents and give a lot of color to the } \\
\text { wall to make it look more beautiful. }\end{array}$ & \\
\hline
\end{tabular}

Source: Pinterest (2017)

\section{Precedent}
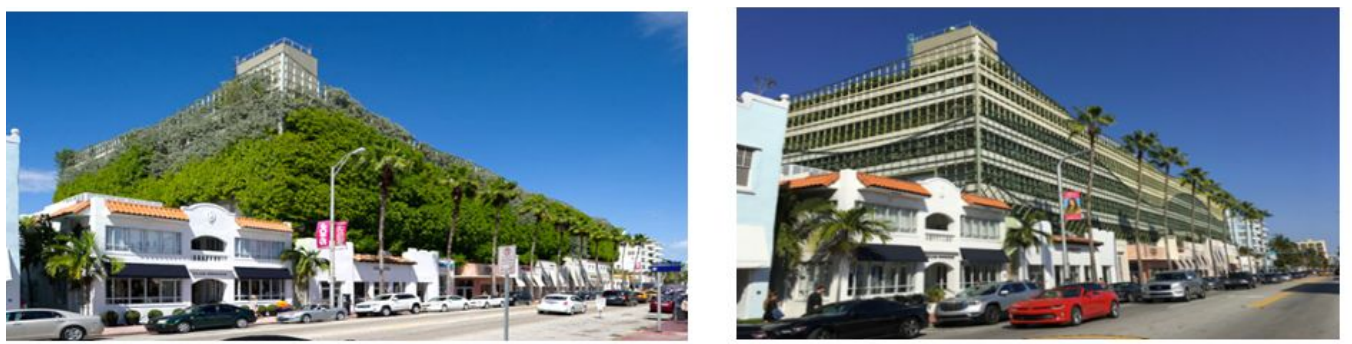

Figure 1. Vertical Green Application on Urban Corridor Source: Pinterest (2017)

In dense urban corridor environments, vertical garden applications are generally located on the upper floors with the aim of not interfering with human activities, giving shadows on the upper floors. Thus vertical garden applications can provide environmental and visual improvement benefits in city corridors. 


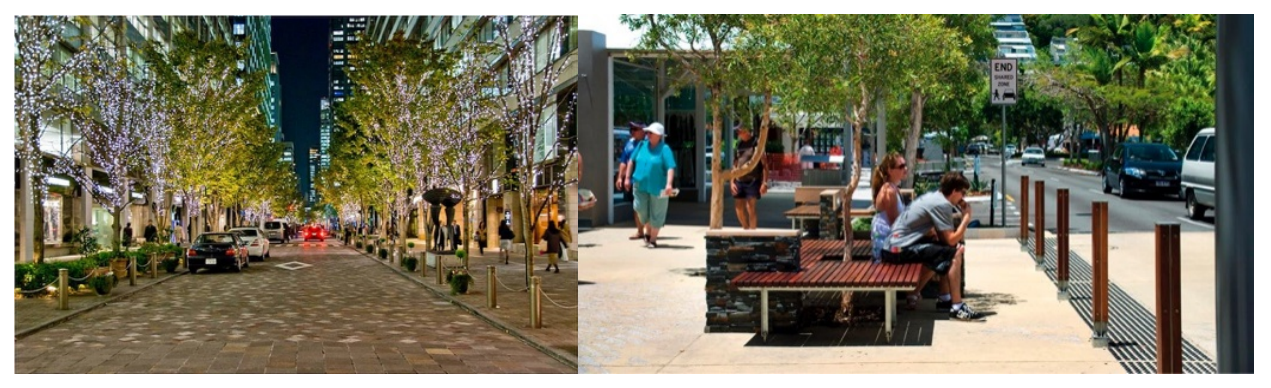

Figure 2. Streetscape of urban corridor Source: Pinterest (2017)

\section{Research Method}

This research used descriptive qualitative and explorative method with emphasized in people participation as a consideration in deciding the concept and design of the study area. Primary data for this research were collected through observation and focus group discussion (FGD). Considering the community is the subject and object of the undertaken design process, involving the community in a design process is an important thing. Community involvement consist of several stakeholders chosen based on their expertise sit together to discuss about Kembang Jepun. The engagement is conducted using Focus Group Discussion (FGD) by gathering the stakeholders in one event, and each of them can give their opinion on the issue based on their knowledge. Stakeholders as participating in the FGD are coming from various backgrounds yet similar in topic of interest. Government, expert, academia, students and also local inhabitants are included as stakeholders. In a facilitated session that last from hours to around two days, ideas are presented to the participants, after which professional facilitators will ask for people's reactions to the proposals that have been shown to them (The local agenda 21 planning guide, 1996)[5]. FGD is organized to gather information and issue from people's perception and then to disseminates the recommendation by authors. FGD as public meetings is considered an urban planning and design tool by involving public in the decision-making process and it can also be used to disseminate information.

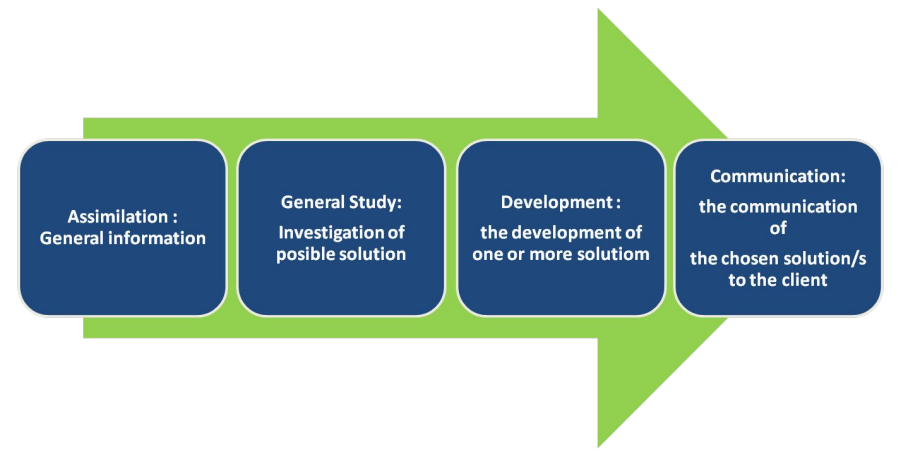

Figure 3. Urban Design Process

Source : (based on RIBA practice and Management Handbook in Moughtin, 1999) 
According to the RIBA practice and management handbook, design process is divided into four phases as shown in figure 1 (Moughtin, 1999)[6]. Phase 1 is Assimilation: the accumulation of general information and information specially related to the problem, Phase 2 is General Study: the investigation of the nature of the problem: the investigation of possible solutions. Phase 3 is Development: the development of one or more solutions and Phase 4 is Communication: the communication of the chosen solution/s to the client

At the first stage, researchers collect the information regarding Kembang Jepun as an old district in Surabaya city and its phenomenon of urban landscape and streetscape. Authors then decided a suitable district as area of research. The second stage is conducted by investigating the problems and potentials in the research area, and delved into case studies and precedents to learn about existing innovative solutions. To achieve the research objective, investigation of potentials-issues is divided into three dimensions of sustainability: environmental, social and economic. The third stage is to develop a design concept from the criteria. The last stage is to hold FGD and share the concept of innovative planning in a presentation. At the final stage, advices and recommendations from various stakeholders are treated as valuable inputs for the research. The major interest of the research is to combine between authors' idea and community's perception in creating sustainable urban streetscape in Surabaya old district, specifically Kembang Jepun main road.

\section{RESULT AND DISCUSSION}

The dominance of trade and services as well as offices makes the movement of pedestrians in this region quite crowded. Especially on the main road corridors such as Jalan Kembang Jepun. Pedestrian path on this road already meets the standards. But there are some parts that have begun to damage the pavement. In addition, there are vehicles that not supposed to park on the pedestrian lane. In the business area, the condition of pedestrian way is not adequate, especially since some roads still do not have pedestrian way.

The criteria for main road of Kembang Jepun is:

1. Traffic flow and street furniture should be able to improve the performance of the road and streetscape.

2. The design should be visually appealing to improve the atmosphere and visual quality of the area.

3. The design should pay attention to landmarks and spirit of place to strengthen the identity of Kembang Jepun area.

4. The design should be able to accommodate various activities for different group of people and utilize building as background for activities

5. The design of public space should consider its local content and involve local communities 

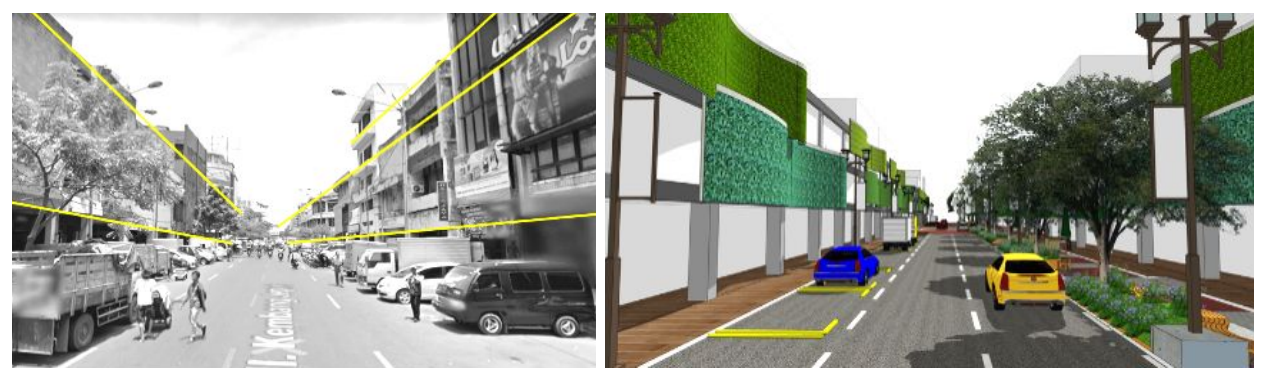

Figure 4. Before and after of jl. Kembang Jepun Source: Author, 2017

Given the uneven performance of Kembang Jepun (dense in working hours but quiet afterwards), it is found several causes of this happening, namely:

1. Commercial functions that fill the rows of buildings along the corridor.

2. Buildings along the corridor form a liner line that accelerates the rate of corridor users, this is coupled with linear current flow.

3. Rows of car parks that fill the roads that worsen the atmosphere of the corridor.

Vertical garden is used for ecological use and to reduce the urban heat in Kembang Jepun Area. Vertical garden applied on the facade of the building is used to add a dynamic impression on the building by creating a curved pattern. The pattern is applied using wiremesh as the planting media of vertical garden.
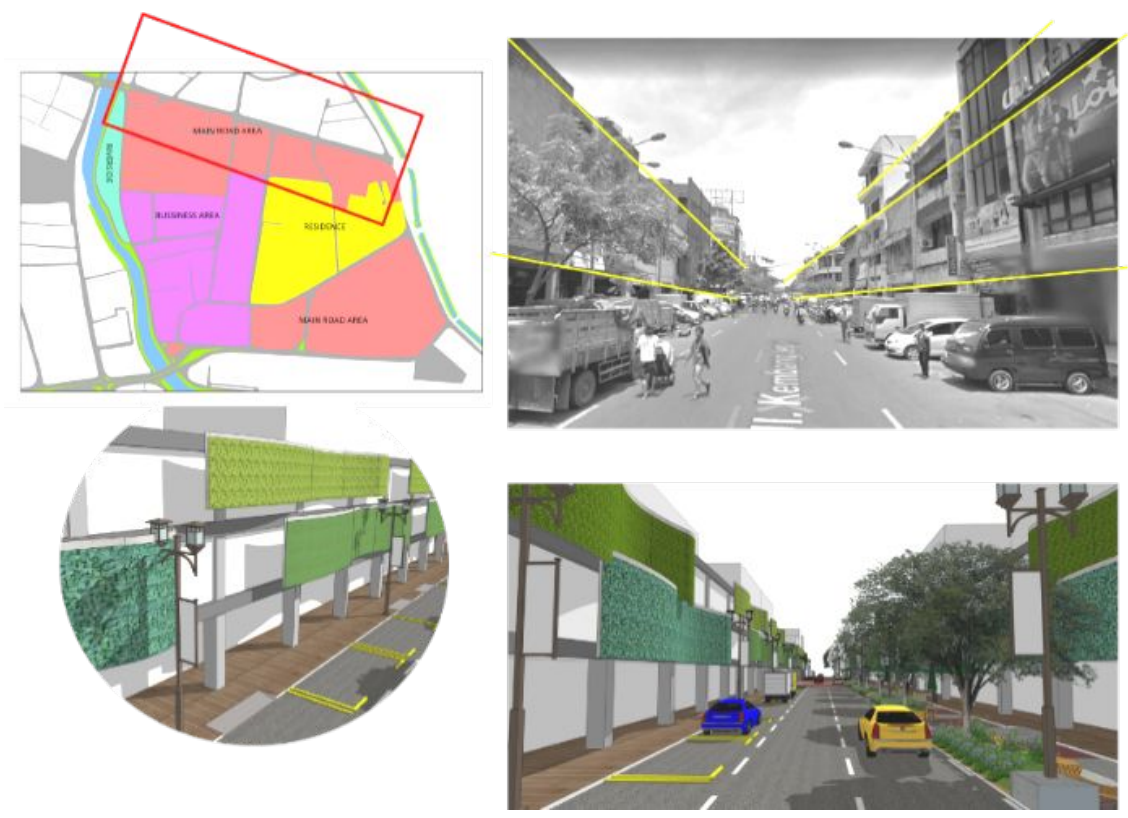

Figure 5. Façade vertical garden at $\mathrm{Jl}$. Kembang Jepun Source : Author, 2017 
The number of motorized paths will be reduced to 3 lines. On the right side of the reduced path will be used as a pedestrian way and added with some softscape and hardscape elements. In addition to pedestrian way can also be used for street vendors at night, so installed some elements of street furniture to support economy activities at night.
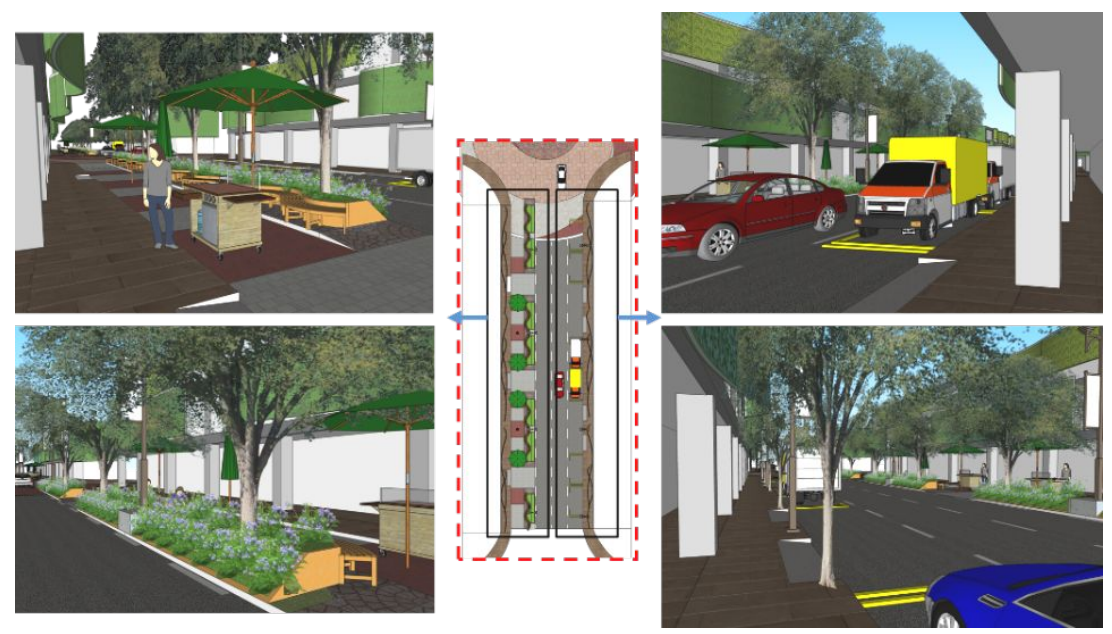

Figure 6. Streetscape for each Side Source : Author, 2017

At the junction of Jalan Kembang Jepun, applied a concept that aims to form the active outer space achieved by redesigning the surface of the road material, thus forming a distinctive outer space. The design of the intersections is inspired by the oriental design with the aim of enhancing vernacular imagery from the study site. Road material uses surface material that has excellent absorption.
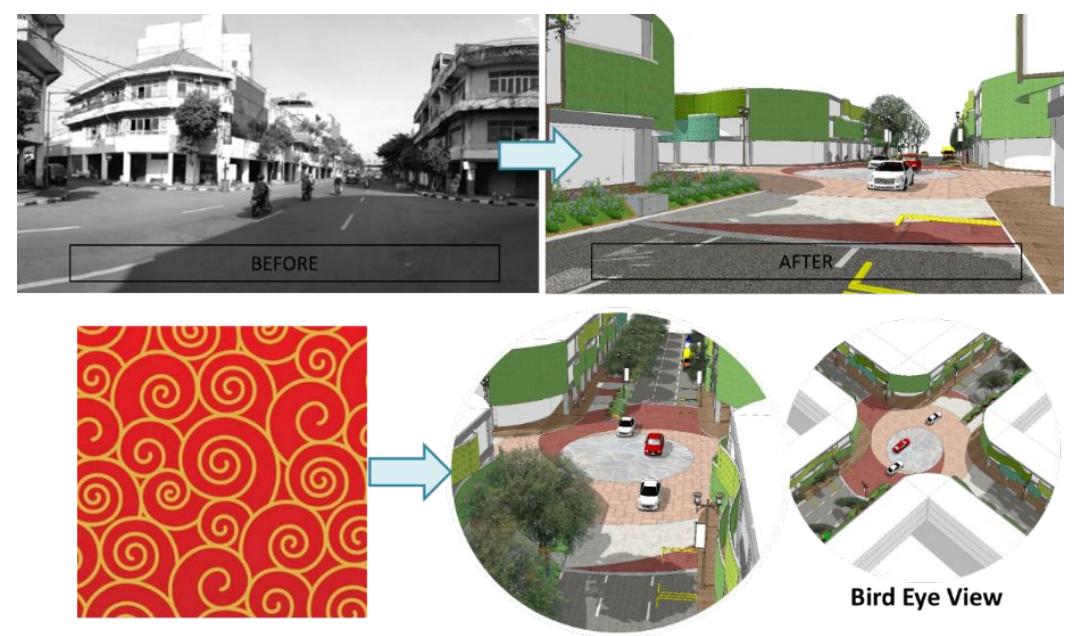

Figure 7. The Design of Intersection Source : Author, 2017 
The pattern at the intersection J1. Kembang Jepun is used to reinforce the image of the Kembang Jepun area that is identical with the old city that reinforces the pecinan characteristic as a regional character.

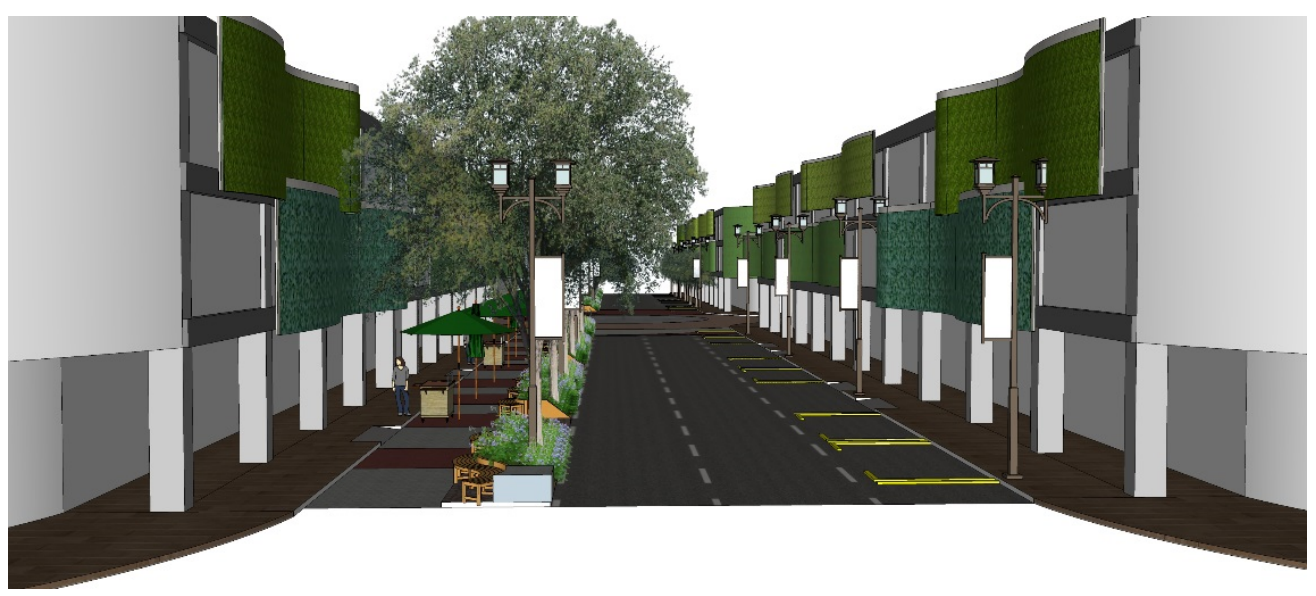

Figure 8. The Green Façade concept of the Corridor Source : Author, 2017

In the streetscape of $J l$. Kembang Jepun there are additional lines for pedestrian located on both sides of the road. At the left side of the expansion path for pedestrian there is also an area for the green line which is also used as a barrier between motor vehicles and pedestrians. Aside from being a pedestrian lane, the extension of the path can also be used for street vendors around the kembang jepun area to attract visitors interest in the area to better utilize the pedestrian path. In addition there are also additional street furniture that is used to complete the facilities pedestrian way so that it can be used both during the day and night. Some street furniture added are:

Table 2. Street Furniture for Kembang Jepun streetscape

\begin{tabular}{ll} 
No. $\begin{array}{c}\text { Street } \\
\text { furniture }\end{array}$ & \multicolumn{1}{c}{ Explanation } \\
\hline 1 Street Lamp & The addition of street \\
& lamp is used for the \\
& lighting of the Kembang \\
& Jepun to illuminate the \\
& area for night activities. In \\
& addition, the lighting at \\
& night is also intended to \\
& provide a sense of security \\
& and comfort for visitors \\
& who visit Kembang Jepun \\
& at night.
\end{tabular}


Table 2. Street Furniture for Kembang Jepun streetscape (continued)

\begin{tabular}{|c|c|c|c|}
\hline No. & $\begin{array}{c}\text { Street } \\
\text { furniture }\end{array}$ & Explanation & Picture \\
\hline 2 & Bench & $\begin{array}{l}\text { Bench is used to provide a } \\
\text { sense of comfort for } \\
\text { pedestrians through the } \\
\text { pedestrian way. It is also } \\
\text { used to serve as a mean of } \\
\text { sightseeing around the } \\
\text { area of Kembang Jepun. }\end{array}$ & \\
\hline 3 & Street vendor & $\begin{array}{l}\text { The addition of street } \\
\text { vendors here is to create } \\
\text { activities on the night and } \\
\text { revive culinary tourism on } \\
\text { the area. This is also done } \\
\text { to eliminate the } \\
\text { impression of dark and } \\
\text { gloomy Kembang Jepun } \\
\text { at night. Trade activity in } \\
\text { pedestrian way area is also } \\
\text { used to improve economic } \\
\text { aspect of small and } \\
\text { medium society. }\end{array}$ & \\
\hline 4 & Soft scape & $\begin{array}{l}\text { Softscapes in form of } \\
\text { various trees, shrubs, and } \\
\text { grass give the area a softer } \\
\text { and more natural looking } \\
\text { image, making Kembang } \\
\text { Jepun more approachable } \\
\text { and friendlier. Softscapes, } \\
\text { green wall, and vertical } \\
\text { gardens along the road } \\
\text { also create a cooler } \\
\text { microclimate and more } \\
\text { interesting view for } \\
\text { visitors. }\end{array}$ & \\
\hline
\end{tabular}
Source : Author, 2017

The picture on the side shows the view of the Kembang Jepun road seen from above. The image shows a very clear division of paths between motor vehicles, pedestrians and green path. This is applied to create a clear edge of the mobilization. In addition, the clear edges is also applied to create an innovative streetscape quality and can provide comfort for all aspects of the community in the Kembang Jepun area. 


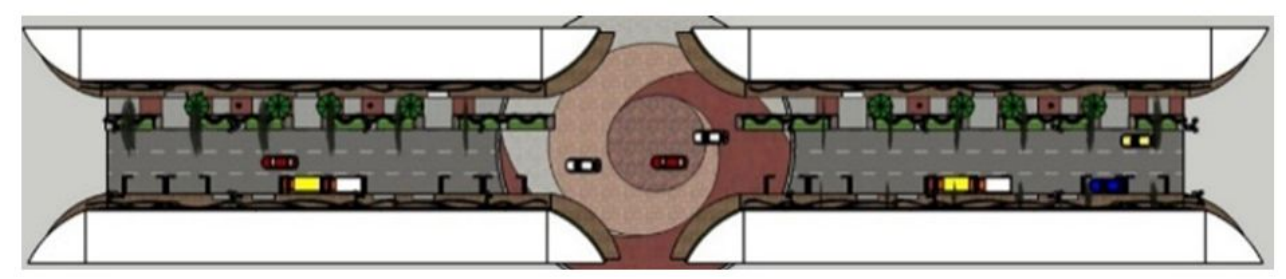

Figure 9. Picture from above

Source : Author, 2017

Kembang Jepun Area is one of the busiest area in North Surabaya. The existence of business places along the road creates a disorder on Kembang Jepun road. It is important to apply an innovative streetscape arrangement on this corridor. Streetscape arrangement applied on along the corridor of Kembang Jepun road. This arrangement includes the addition of pedestrian way, as well as reduction of motor vehicle lane to slow down the vehicle path. Street furniture are also as aesthetic element that adds comfort and improves security for pedestrians. To improve the ecological quality, green path is added as a barrier between pedestrian way and motorway.

\section{CONCLUSION}

Kembang Jepun is known as a dense area filled with commercial buildings and poor condition of the streetscape. As a historic area that continues to operate actively, Kembang Jepun corridor can be developed to produce an attractive downtown area environmentally, socially, and economically. The criteria for main road of Kembang Jepun can be concluded as such: traffic flow and street furniture should be able to improve the performance of the road and the streetscape, the design should be visually appealing and pay attention to landmarks and spirit of place, the design should be able to accommodate various activities for different group of people and utilize building as background for activities, and the design of public space should consider its local content and involve local communities.

Innovative design of the streetscape in Kembang Jepun corridor is derived from various ideas and considerations through discussion between stakeholders. The design has several important points:

1. Vertical garden is used for its ecological benefit to reduce the urban heat in Kembang Jepun Area and is applied on the facade of the building to add a dynamic impression. 
2. The number of motorized paths will be reduced to 3 lines to give more space for pedestrian way. The pedestrian way can also be used for street vendors at night.

3. The junction of the road is designed as an active outer space with patterns that sthrengthen its identity as an old pecinan area.

4. Green line is used as a barrier between motor vehicles and pedestrians.

\section{REFERENCES}

The Abu Dhabi Planning Council (2010), Abu Dhabi Street Design Manual https://issuu.com/cdaadmin/docs/street_design_manual_english_small_final

Yu-Peng Yeh (2010), Green Wall The Creative Solution in Response to the Urban Heat Island Effect (Taichung: National Chung-Hsing University)

Rath and Kieß1 in Ottelé et al. (2011), Vertical greening systems and the effect on air flow and temperature on the building envelope, Build and Env. 46, 228794

Sunakorn, P. et al. (2011), Thermal performance of biofacade with natural entilation in the tropical climate Procedia Engineering. 21, 34-41

ICLEI (1996), An introduction to sustainable development planning, The Local Agenda 21 Planning Guide

Moughtin, C. (1999), Urban Design: Method and Techniques, Architectural Press, Oxford 
Soemardiono, Raxhmawati, Ardianta, Sakinah, Syafiq, Ranuari, Putri, Tuffahati: INNOVATIVE SUSTAINABLE STREETSCAPE DESIGN ALONG KEMBANG JEPUN CORRIDOR SURABAYA

This page is intentionally left blank 